\title{
A Practical Procedure for Vertical Two-dimensional Hydrothermal Simulation by Finite Element Method
}

\author{
By \\ Yusaku YANO* \\ (Received, June 2, 1988., Accepted, Sept. 28, 1988)
}

\begin{abstract}
A procedure for the numerical simulation of a two-dimensional, single phase geothermal hot water convection system was developed. Galerkin's finite element method with triangular elements was applied. The procedure was implemented by FORTRAN and was verified by execution tests. The program was applied to simulation of the natural evolution of a geothermal system to its final steady state. The procedure is based on general conservation equations having accumulation terms, and thus can avoid troubles on convergence which might occur in case the steady state is postulated in the program. The procedure may be applied to the development of simulators effectively used for understanding the physical processes in liquid dominated hydrothermal systems.
\end{abstract}

\section{Introduction}

Numerical simulation in reservoir engineering study has been recognized as a quite useful technique for the evaluation of geothermal resources. It is usually available even if the behavior of a geothermal reservoir is difficult to be treated by analytical methods.

The study covers wide range of reservoir models, from macroscopic natural convection models to microscopic reservoir behavior models. Recently, efforts have been made to apply numerical simulators to geothermal areas. There are some examples of the applications to the modeling of natural state of geothermal systems. BODVARSSON et al. (1984) or INGEBRITSEN et al. (1985) are among them. They used three-dimensional, two-phase simulator for two-phase reservoirs.

As for geothermal systems in Japan, there are many cases in which the system can be analyzed by treating the macroscopic hydrother-

\footnotetext{
* Geological Survey of Japan
}

mal movement of single phase hot water. In those cases, single phase simulator is suitable to be used effectively rather than multi-phase simulator. If there are sufficient data on the system, three-dimensional analysis is desirable, but it is unusual. In general cases, three-dimensional analysis makes the problem complicated unnecessarily, while the spatial precision is forced to be low for computational time. In the examples mentioned above, the models are two-dimensional vertical sections, though the simulators are capable of treating threedimensional models. Vertical two-dimensional models are more applicable than areal models, to the study of physical processes, because the effect of gravity has an important role in hydrothermal convection.

Therefore, a single phase, vertical two-dimensional simulator which is easy to be developed and used is required at an early stage for the analysis of the natural state of a geothermal system.

Capabilities for good approximations of the reservoir are required for the simulator. The 
capabilities would be those of treating arbitrary reservoir shapes, steady and transient flows, rock properties of individual blocks of the reservoir, adequate fluid properties and boundary conditions. On the other hand, easiness for data preparatin and calculation efficiency may be practically very important. Developing a model of a geothermal system requires repetition of simulation executions with different input data.

In order to develop such a simulator, finite element method (FEM) seems to be the best discretization procedure. There are three methods which are usually used for the discretization of governing equations. They are FEM, finite difference method (FDM), and integrated finite difference method (IFDM). Since the movement of hot water is considerably affected by the shape of the reservoir, FEM and IFDM, which are capable of treating arbitrary reservoir shape, are preferble. Input data for FEM may be prepared more easily than for IFDM, for the specification of relations among elements in the latter method is rather complicated.

MERCER and FAUST (1975) presented a procedure for two-dimensional (areal), two-phase reservoir by GALERKIN'S FEM. The procedure can be modified into a proceduce for our purpose. HANAOKA (1980) presented a detailed procedure for a vertical two-dimensional reservoir with triangular elements. It treated only steady state of the reservoir. The purpose of this paper is to describe a procedure by FEM capable of treating both transient and steady state of a vertical two-dimensional reservoir, by introducing a discretization procedure to the basic conservation equations (FAUST and MERCER, 1979) based on the procedures mentioned above. The simulator developed by this procedure is capable of handling various flow phenomena. It has advantages inherent in FEM, such as the capabilities for treating arbitrary shape of sections, easiness for treating boundary conditions or heterogeneity and anisotropy of permeability.
Also, problems in the study of the relation between steady state flow of a natural geothermal system and transient flow may be discussed using this procedure.

\section{Basic equations and discretization}

For developing natural convection models, finite element models of liquid dominated systems are suitable. HANAOKA (1980) developed a procedure applying GALERKIN'S FEM to liquid hydrothermal system. But it employed steady state assumption, neglecting accumulation terms in conservation equations. MERCER and FAUST (1975) described the approximation of the time derivative using finite difference techniques. Combining these, a simple and efficient discretization procedure can be derived.

FAUST and MERCER (1979) described general basic equations for the conservation of mass and energy of two phase steam and water flow. Assuming that steam is absent, the equations for liquid system become

$$
\begin{aligned}
& \frac{\partial(\phi \rho)}{\partial t}-\nabla \cdot\left[\frac{k \rho}{\mu} \cdot(\nabla p-\rho g \nabla D)\right] \\
& -q_{m}=0 \\
& \frac{\partial}{\partial t}\left[\phi \rho h+(1-\phi) \rho, h_{r}\right] \\
& -\nabla \cdot\left[\frac{k \rho h}{\mu} \cdot(\nabla p-\rho g \nabla D)\right]^{-}\left(\lambda\left(\frac{\partial T}{\partial p}\right)_{h} \nabla p+\lambda\left(\frac{\partial T}{\partial h}\right)_{p} \nabla h\right) \\
& -\nabla \cdot[\lambda] \\
& -q_{h}=0
\end{aligned}
$$

The meanings of variables in the equations of this paper are explained in the nomenclature.

The approximation below is appropriate for most of single phase liquid systems.

$$
\begin{aligned}
& \lambda\left(\frac{\partial T}{\partial p}\right)_{h} \nabla p+\lambda\left(\frac{\partial T}{\partial h}\right)_{p} \nabla h \\
& =\frac{\lambda}{C} \nabla h
\end{aligned}
$$

for temperature is assumed to depend only on enthalpy. Assuming that the fluid density depends only on temperature (and so enthalpy) 
and porosity is uniform over an element and constant, the accumulation term in the mass balance becomes

$$
\frac{\partial(\phi \rho)}{\partial t}=\phi\left(\frac{\partial \rho}{\partial h}\right)_{\partial} \frac{\partial h}{\partial t}
$$

If the enthalpy of rock depends only on temperature, and specific heat capacity of rock is uniform and constant, we get

$$
\frac{\partial h_{r}}{\partial t}=\frac{C_{r}}{C} \frac{\partial h}{\partial t}
$$

We assume that the density of rock is constant. Then we can write accumulation term in the energy balance equation as

$$
\begin{aligned}
& \frac{\partial}{\partial t}\left[\phi \rho h+(1-\phi) \rho_{r} h_{r}\right] \\
& =\int \phi h\left(\frac{\partial \rho}{\partial h}\right)_{P}+\phi \rho \\
& \left.\quad+(1-\phi) \rho_{r} \frac{C_{r}}{C}\right] \frac{\partial h}{\partial t}
\end{aligned}
$$

If we do not consider heat source within an element except for that specified as

$$
q_{h}=h q_{m}
$$

we can simplify the energy equation (2) as

$$
\begin{aligned}
& {\left[(1-\phi) \rho \cdot \frac{C r}{C}+\phi \rho\right) \frac{\partial h}{\partial t}} \\
& -\nabla h \cdot\left[\frac{k \rho}{\mu} \cdot(\nabla p-\rho g \nabla D)\right] \\
& -\frac{\lambda}{C} \nabla^{2} h=0
\end{aligned}
$$

The permeability major axes are assumed to be orthogonal. We use following substitutions

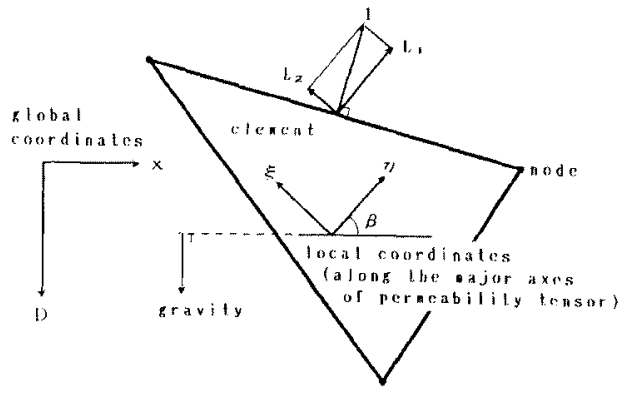

Fig. 1 Relation between the coordinates and an element. for simplification.

$$
\frac{k \rho}{\mu}=\frac{\rho}{\mu}\left(\begin{array}{cc}
k_{1} & 0 \\
0 & k_{2}
\end{array}\right)=\left(\begin{array}{cc}
A_{1} & 0 \\
0 & A_{2}
\end{array}\right)
$$

For application of triangular elements, we consider the local coordinates $(\eta, \xi)$ as in Fig. 1. After substituting (4) for the accumulation term in (1), and multiplying it by an interpolation function $\mathrm{N}_{i}$, we take the integral for an element.

$$
\begin{aligned}
& \phi \iint_{v} N_{i}\left[\left(\frac{\partial \rho}{\partial h}\right)_{p} \frac{\partial h}{\partial t}\right) d \eta d \xi \\
& -\iint_{{ }} N_{i}\left(A_{1} \frac{\partial}{\partial \eta}\left(\frac{\partial p}{\partial \eta}+\rho g \sin \beta\right)\right. \\
& +A_{2} \frac{\partial}{\partial \xi}\left(\frac{\partial p}{\partial \xi}+\rho g \cos \beta\right) \\
& +\frac{\partial A_{1}}{\partial \eta} \frac{\partial p}{\partial \eta}+\frac{\partial A_{2}}{\partial \xi} \frac{\partial p}{\partial \xi} \\
& +o g\left(\frac{\partial A_{1}}{\partial \eta} \sin \beta+\frac{\partial A_{2}}{\partial \xi} \cos \beta\right) \\
& \left.+q_{m}\right) d \eta d \xi=0
\end{aligned}
$$

Integration by parts for (10) as in ZIENKIEWICZ (1971) results in

$$
\begin{aligned}
& \phi \iint_{v} N_{i}\left[\left(\frac{\partial \rho}{\partial h}\right)_{o} \frac{\partial h}{\partial t}\right] d \eta d \xi \\
& +\iint_{0}\left[A_{1} \frac{\partial N_{i}}{\partial \eta} \frac{\partial p}{\partial \eta}+A_{2} \frac{\partial N_{i}}{\partial \xi} \frac{\partial p}{\partial \xi}\right. \\
& +A_{1} \frac{\partial N_{i}}{\partial \eta} \rho g \sin \beta+A_{2} \frac{\partial N_{i}}{\partial \xi} \rho g \cos \beta \\
& \left.-N_{i} q_{\mathrm{m}}\right] \mathrm{d} \eta \mathrm{d} \xi-\oint_{s} N_{i}\left[A _ { 3 } \left(\frac{\partial p}{\partial \eta}\right.\right. \\
& +\rho g \sin \beta) L_{1}+A_{2}\left(\frac{\partial p}{\partial \xi}\right. \\
& \left.\quad+\rho g \cos \beta) L_{2}\right] d S=0
\end{aligned}
$$

where $L_{i}$ and $L_{\text {sare }}$ the direction cosines of outward normal of the element boundary (Fig. 1).

Pressure and enthalpy within an element are assumed to be the linear combinations of values at three nodes of the element as

$$
\begin{aligned}
& p=N_{1} p_{1}+N_{2} p_{2}+N_{3} p_{3}=N_{j} p_{1} \\
& h=N_{1} h_{1}+N_{2} h_{2}+N_{3} h_{3}=N_{j} h_{i}
\end{aligned}
$$

Pressure of a node is denoted as

$$
p_{j}=\theta p_{j}^{t+\Delta t}+(1-\theta) p_{j}^{t}
$$


If $\theta$ equals to 1 , it implies that fully implicit time difference scheme is adopted.

Time derivative of enthalpy is written as

$$
\frac{\partial h}{\partial t}=\frac{h^{t+\Delta t}-h^{t}}{\Delta t}=\frac{N_{j} h_{j}^{l+\Delta t}-N ; h_{j}^{i}}{\Delta t}
$$

Taking substitutions

$$
E_{i j}=\iint_{0}\left(A_{1} \frac{\partial N_{i}}{\partial \eta} \frac{\partial N_{j}}{\partial \eta}+A_{2} \frac{\partial N_{i}}{\partial \xi} \frac{\partial N_{i}}{\partial \xi}\right) d \eta d \xi
$$

$$
\begin{aligned}
& F_{i}=\iint_{v}\left(A_{\mathrm{t}} \frac{\partial N_{i}}{\partial \eta} \rho g \sin \beta+A_{2} \frac{\partial N_{i}}{\partial \xi} \rho g \cos \beta\right. \\
&\left.-N_{i} q_{m}\right) d \eta d \xi
\end{aligned}
$$

$$
H_{i j}=\theta E_{i j}
$$

$$
\begin{aligned}
I_{i} & =\frac{\phi}{\Delta t}\left(h_{j}^{t+\Delta t}-h_{j}^{b}\right) \iint_{i} N_{i} N_{j}\left(\frac{\partial \rho}{\partial h}\right)_{\rho} d \eta d \xi \\
& -p_{i}^{i} \frac{\phi}{\Delta t} \iint_{i} N_{i} N_{j}\left(\frac{\partial \rho}{\partial p}\right)_{h} d \eta d \xi \\
& +(1-\theta) E_{i j} p_{j}^{i}
\end{aligned}
$$

and

$$
\begin{aligned}
S_{i} & =f_{s} N_{i}\left(A_{i}\left(\frac{\partial p}{\partial \eta}+\rho g \sin \beta\right) L_{1}\right. \\
& \left.+A_{2}\left(\frac{\partial p}{\partial \xi}+\rho g \cos \beta\right) L_{2}\right] d \eta d \xi(20),
\end{aligned}
$$

then the discretized mass balance equation (11) becomes

$$
H_{i j} p_{i}^{t+\Delta t}+I_{i}+F_{i}-S_{i}=0
$$

where $p_{j}^{t+\Delta t}$ is the unknown variable.

The same procedure can be applied to the energy balance equation (8) .

Assuming

$$
h_{j}=\theta h_{j}^{t+\Delta t}+(1-\theta) h_{j}^{l}
$$

and substituting

$$
\begin{aligned}
G_{i j} & =\iint_{u}\left(A_{1} N_{i} \frac{\partial N_{i}}{\partial \eta}\left(\frac{\partial p}{\partial \eta}+\rho g \sin \beta\right)\right. \\
& +A_{2} N_{i} \frac{\partial N_{j}}{\partial \xi}\left(\frac{\partial p}{\partial \xi}+\rho g \cos \beta\right) \\
& \left.-\frac{\lambda}{C}\left(\frac{\partial N_{i}}{\partial \eta} \frac{\partial N_{j}}{\partial \eta}+\frac{\partial N_{i}}{\partial \xi} \frac{\partial N_{j}}{\partial \xi}\right)\right] d \eta d \xi
\end{aligned}
$$

$$
\begin{aligned}
S_{i} & =f_{s} \frac{\lambda}{C} N_{i}\left(\frac{\partial h}{\partial \eta} L_{1}+\frac{\partial h}{\partial \xi} L_{2}\right) d S \\
J_{i j} & =\frac{1}{\Delta t} \iint_{\nu} N_{i} N_{j}\left((1-\phi) \rho \frac{C_{r}}{C}+\right. \\
& \phi \rho) d \eta d \xi-\theta G_{i j} \\
O_{i} & =-\frac{h_{j}^{i}}{\Delta t} \iint_{i} N_{i} N_{j}\left((1-\phi) \rho \frac{C_{r}}{C}\right. \\
& +\phi \rho) d \eta d \xi-(1-\theta) G_{i j} h_{j}^{i}
\end{aligned}
$$

the discretized energy balance equation ( 8 ) becomes

$$
J_{i j} h_{j}^{t+\Delta_{t}}+O_{i}-S_{i}=0
$$

where $h_{i}^{t+\Delta t}$ is the unknown variable.

Linear interpolation function $N_{i}$ can be written as

$$
N_{\mathrm{i}}=\frac{1}{2 M}\left(b_{1}+b_{3 i} \eta+b_{3 i} \xi\right)
$$

where $M$ is the area of the element.

Considering differentials and integrals of $N_{i}$, such as

$$
\iint_{\nu} N_{i} N_{j} d \eta d \xi=\left\{\begin{array}{l}
\frac{M}{12}(\mathrm{i} \neq \mathrm{j}) \\
\frac{M}{6}(\mathrm{i}=\mathrm{j})
\end{array}\right.
$$

we can rewrite the coefficients of the equations (21) and (27) as follows;

$$
\begin{aligned}
& E_{i j}=\frac{1}{4 M}\left(A_{1} b_{2,} b_{2 j}+A_{2} b_{3 i} b_{3 i}\right) \\
& F_{i}=\frac{\rho g}{2}\left(A_{i} b_{2 i} \sin \beta+A_{2} b_{3 i} \cos \beta\right)-\frac{M}{3} q_{m}
\end{aligned}
$$

$$
\begin{aligned}
G_{i j} & =\frac{1}{6}\left[A_{1} b_{2 j}\left(\frac{\partial p}{\partial \eta}+\rho g \sin \beta\right)\right. \\
& \left.+A_{2} b_{3 j}\left(\frac{\partial p}{\partial \xi}+\rho g \cos \beta\right)\right] \\
& -\frac{\lambda}{C} \frac{1}{4 M}\left(b_{2 i} b_{i j}+b_{3 i} b_{3 j}\right) \\
I_{i} & =\frac{\phi}{\Delta t} a_{i j}\left(\left(h_{j}^{i+\Delta i}-h_{j}^{t}\right)\left(\frac{\partial \rho}{\partial h}\right)_{p}\right) \\
& +(1-\theta) E_{i j} p_{j}^{i}
\end{aligned}
$$




$$
\begin{aligned}
J_{i j} & =\frac{1}{\Delta t} a_{i j}\left[(1-\phi) \rho \frac{C_{r}}{C}+\phi \rho\right) \\
& -\theta G_{i j} \\
O_{i} & =-\frac{h_{j}^{i}}{\Delta t} a_{i j}\left[(1-\phi) \rho \frac{C_{r}}{C}+\phi \rho\right) \\
& -(1-\theta) G_{i j} h_{j}^{t} \\
a_{i j} & =\left(\begin{array}{l}
\frac{M}{12}(\mathrm{i} \neq \mathrm{j}) \\
\frac{M}{6}(\mathrm{i}=\mathrm{j})
\end{array}\right.
\end{aligned}
$$

Starting from initial values, pressure and enthalpy can be calculated by (21) and (27). All the other variables can be calculated from these two variables by approximation functions for state equations. The calculation of flow can be performed easily by using interpolation function.

\section{Considerations for programming}

Fig. 2 is the simplified flow chart of the program for the simulation by the proceduce described above.

We start with data input (1)). Parameters for calculation are, time step interval, maximum time, maximum iteration number, $\theta$, maximum deviation for iteration. As the reservoir parameters, we need the coordinates of nodes, the relation between element numbers and nodal numbers, and rock properties such as permeability, thermal conductivity or specific heat capacity, etc.. Boundary conditions may be either Dirichlet type or Neumann type, pressure and enthalpy conditions. Sinks or sources $q_{m}$ can be specified. Following the assumption (7), $q_{h}$ is automatically calculated. Initial pressure and enthalpy values must be specified for each node.

In order to clearly understand the whole conditions we set, we had better have a graphic view of the element system. A printer output of the values we input helps to check them (2)).

We must calculate the coefficients $b_{i j}$ of the interpolation function for each element from

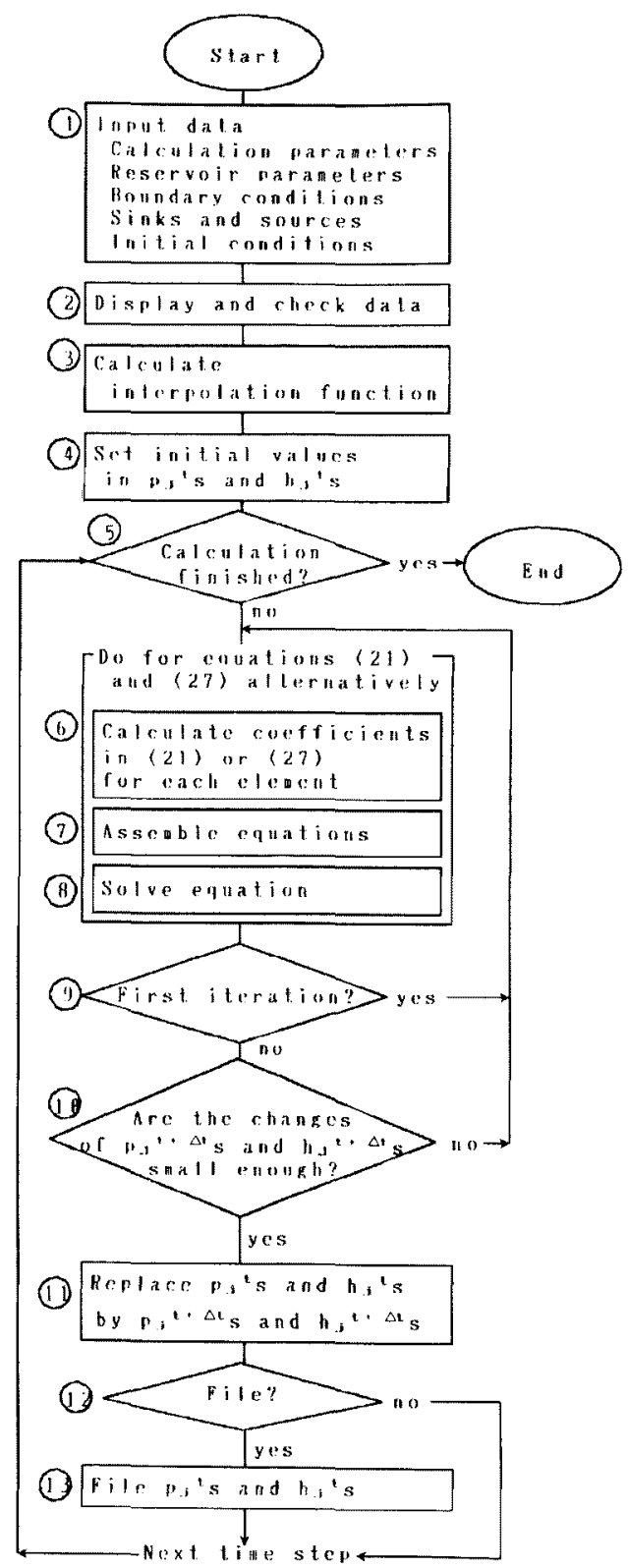

Fig. 2 Flow chart of the FORTRAN program for hydrothermal simulation.

the coordinates of nodes and the direction of the local coordinate $(\eta, \xi)$ specified by the major axes of the permeability tensor (3)). 
We must set the initial values of pressure and enthalpy into dimensioned variables of the program $p_{j}^{t} s$ and $h_{j}^{t} s$ (4)).

At each iteration (6) - (8), $p_{j}^{t+\Delta t} s$ and $h_{j}^{t+\Delta t} s$, are calculated. If the difference between calculated values and the values of the former iteration becomes negligible, we stop the iteration and go on to the next time step.

In the procedure in this paper, mass and energy balance equations are linearlized by GALERKIN'S method for pressure and enthalpy respectively, and adapted for the iteration. On the other hand, Newton Raphson iteration may be generally used to solve nonlinear equations as in hydrothermal simulation. In Newton Raphson method, the original nonlinear equation

$$
f\left(x_{i}\right)=0
$$

is used to create a linear equation for one variable $x_{i}^{n+1}$ by

$$
f\left(x_{i}^{n}\right)+\left.\frac{\partial f}{\partial x_{i}}\right|_{n}\left(x_{i}^{n+1}-x_{i}^{n}\right)=0
$$

and $x_{i}$ is sought by iteration, where $x_{i}$ specifies one of the unknown variables, and $n$ is the iteration index. This is purely a numerical iteration procedure, and may be used when the equations are difficult to be linearlized through the procedure as in this paper. Anyway, it is favorable to consider mass and energy equations independently for the evaluation of the convergence of them. If the change of one of either pressure or enthalpy is very small, the number of iterations can be reduced by skipping those with the negligible change.

To solve the assembled equation, a mathematical subprogram package for linear equations with band matrix is useful. In order to keep the band-width minimum for the efficiency of calculation, we must be careful in assigning the nodal numbers for elements.

At each iteration of every time step, state variables such as temperature, density, and viscosity are calculated from pressure and enthalpy through state equations. We had better use a suitable approximation function es- pecially for viscosity, because it changes greatly with enthalpy, and affects the movement of water. All the variables must be treated in one unit system such as SI unit in the program, avoiding confusion in calculation.

Some elaborations for calculations, such as automatic time step reduction or restart from filed results are very useful and may reduce computation time required.

Results of calculation are filed and are used for display. In order to get a plain picture of the convection, a display of vectors of water flux and contours of temperature overlaid is most useful. Interactive use of graphic displays with high resolution screen is preferable.

\section{Implementation and test}

The procedure described in this paper was implemented into a FORTRAN program. The computer system used for programming and execution is the SIGMA system (YANO and HANAOKA, 1987) of Geological Survey. A character display and a graphic display were used as $\mathrm{I} / \mathrm{O}$ devices. The program consists of about 40 subroutines including those for displaying, which have total 3,500 lines including comment lines.

In order to assure that the simulator would work correctly, program execution tests should be made. However, there are only a few published results that would be suitable for evaluating the ability and validity of the simulator presented here. Although there is a code comparison study for geothermal reservoir simulators (DOE, 1980), it focuses upon the other aspects of geothermal reservoir, rather than the study of natural convection pattern.

Here, the results of program execution tests with parameters similar to YUSA (1983) are described. It may be an integrated function test of the program for a flow pattern on a vertical section with potential flow and thermal convective flow.

Fig. $3 a$ and $3 b$ are calculated results for reproducing the 1,000 and 5,000 years models in the Fig. 2 of YUSA (1983). Parameters used 


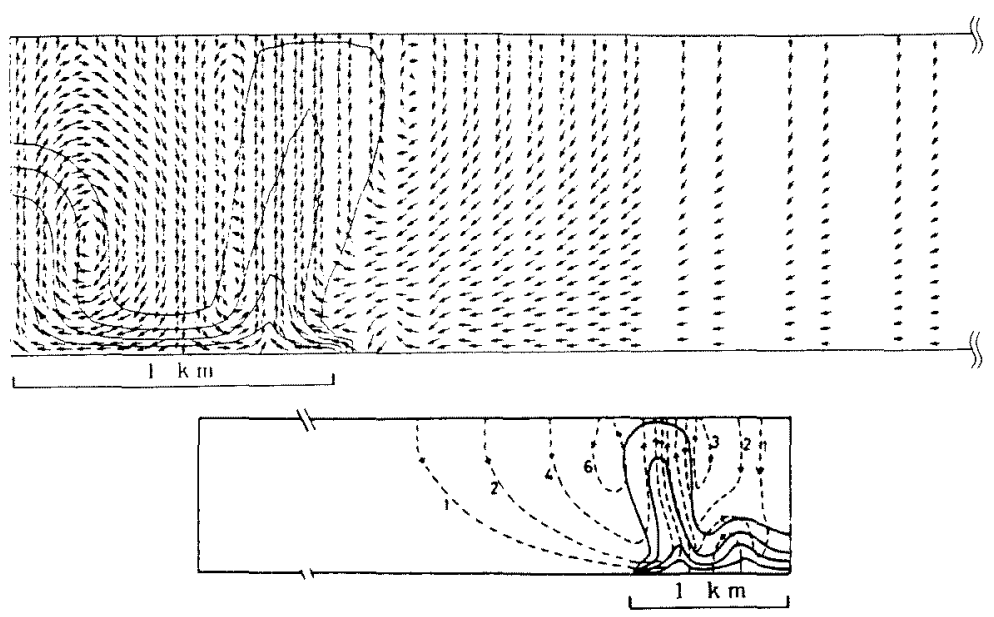

Fig. 3a Upper: Calculated flow and temperature for the program verification test. Input parameters are the same as the published result of Fig. 2 in YUSA (1983) (left-right inverted). They are shown in Table 1. Kinematic viscosity is constant. Elapsed time is 1,000 years. Length of arrows indicates mass flux density in logarithmic scale in thes paper. Temperature contours are for $66^{\circ} \mathrm{C}, 112^{\circ} \mathrm{C}, 158^{\circ} \mathrm{C}$ and $204^{\circ} \mathrm{C}$ respectively from above. The right $2 \mathrm{~km}$ part is not shown.

Lower: Flow pattern and temperature taken from the result at 1,000 years in Fig. 2 in YUSA (1983). Broken lines are contours of nondimensional stream function. Temperatures for the isothermal lines (solid lines) are the same as above.
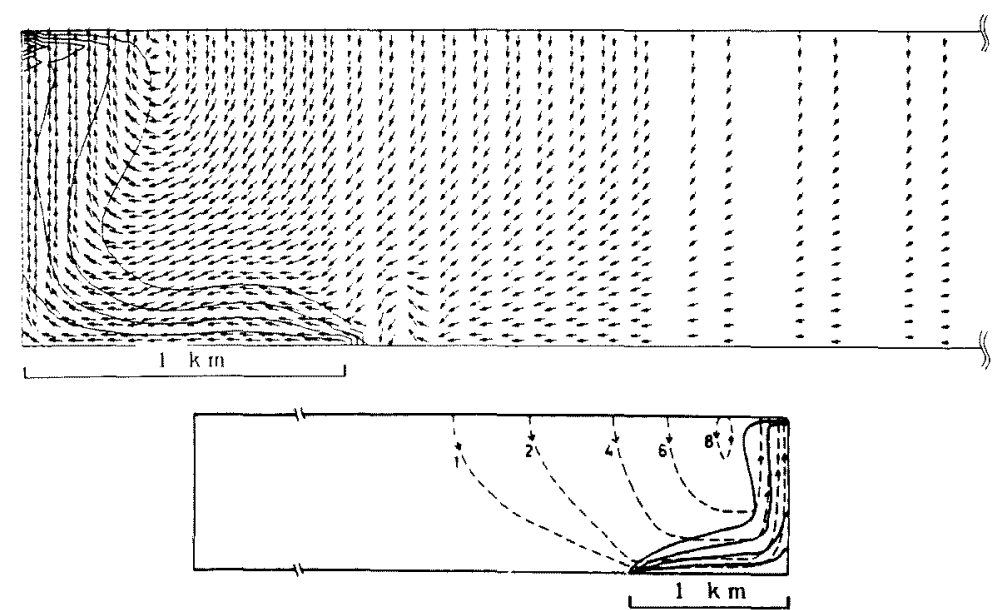

Fig. 3b Upper: Calculated flow (distribution of mass flux density) and temperature with the same parameters as in Fig. 3a. Elapsed time is 5,000 years. Contour values are the same as those of Fig. 3a.

Lower: Flow pattern (contours of nondimensional stream function) and temperature taken from the result at 5,000 years in Fig. 2 in YUSA (1983). 
Table 1 Input parameters for the models of Figures $3 \mathrm{a}, 3 \mathrm{~b}, 4,6 \mathrm{a}$, and $6 \mathrm{~b}$.

\section{Reservoir parameters}

$$
\begin{aligned}
& \text { thickness }=1 \mathrm{~km} \\
& \text { length }=5 \mathrm{~km} \\
& k=1.0 \times 10^{-10} \mathrm{~cm}^{2} \\
& C_{r}=0.152 \mathrm{cal} / \mathrm{g} \cdot{ }^{\circ} \mathrm{C} \\
& \lambda=5.0 \times 10^{-3} \mathrm{cal} / \mathrm{s} \cdot \mathrm{cm} \cdot{ }^{\circ} \mathrm{C} \\
& \phi=0.1 \\
& \rho_{r}=2.7 \mathrm{~g} / \mathrm{cm}^{3} \\
& g=0.98 \mathrm{~m} / \mathrm{s}^{2} \\
& \nu=2.0 \times 10^{-3} \mathrm{~cm}^{2} / \mathrm{s} \text { for Figures } 3 \mathrm{a}, 3 \mathrm{~b} \text {, and } 4 .
\end{aligned}
$$

Approximation for $\mu$ in Fig. 5 is for Figures 6a and 6b.

Approximation for $\rho$ in Fig. 5 is for all models.

Boundary conditions

sides: insurated for both heat and mass

surface: temperature $=20^{\circ} \mathrm{C}$,

$$
\text { pressure }=1 \text { atm for Fig. 3a, 3b, 6a and } 6 \mathrm{~b}
$$

pressure increases leftward for Fig. 4 (1 atm at the right end and the gradient is $1.1661 \mathrm{~atm} / \mathrm{km}$ )

bottom: temperature $=250^{\circ} \mathrm{C}$ for $1 \mathrm{~km}$ from left end

Initial conditions

temperature $=20^{\circ} \mathrm{C}$, pressure $=$ hydrostatic pressure
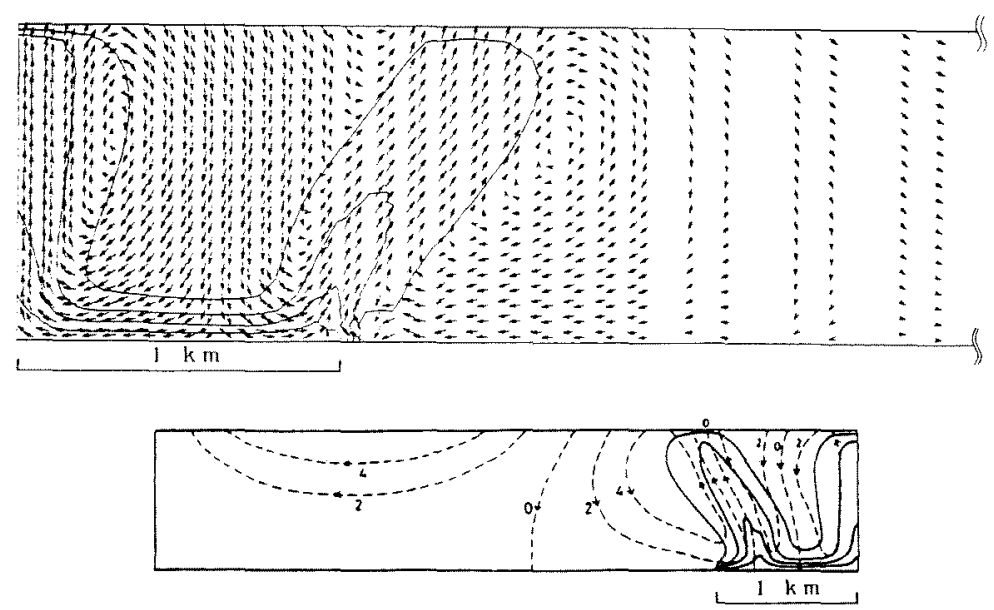

Fig. 4 Upper: Calculated flow (distribution of mass flux density) and temperature with the same parameters as the published result of Fig. 3 in YUSA (1983) (left-right inverted). The parameters are shown in Table 1. Elapsed time is 5,000 years. Contour values are the same as those of Fig. $3 a$.

Lower: Flow pattern (contours of nondimensional stream function) and temperature taken from the result at 5,000 years in Fig. 3 in YUSA (1983). 
are shown in Table 1. The degree of reproduction is quite reasonable. The main hot water plume was formed at the right hand edge of the heat source on the bottom at 1,000 years, and it moved to the edge of the aquifer at later time. This model treats only the thermal convective flow. The change of pattern is almost the same as the result of YUSA (1983).

Fig. 4 is a calculated result for the reproduction of the 5,000 years model in Fig. 3 in YUSA (1983). It involves both thermal convective flow and potential flow. Two major hot water plumes were produced on the heat source. This pattern also follows the result of YUSA (1983) quite well.

As was shown above, it seems that the program works quite reasonably, though there are slight differences between the published result and the calculation by the program. The minor differences are considered to be caused by the differences of mesh configuration, accuracy of approximation and calculation, or some slight differences of parameters used.

In this calculation, kinematic viscosity of

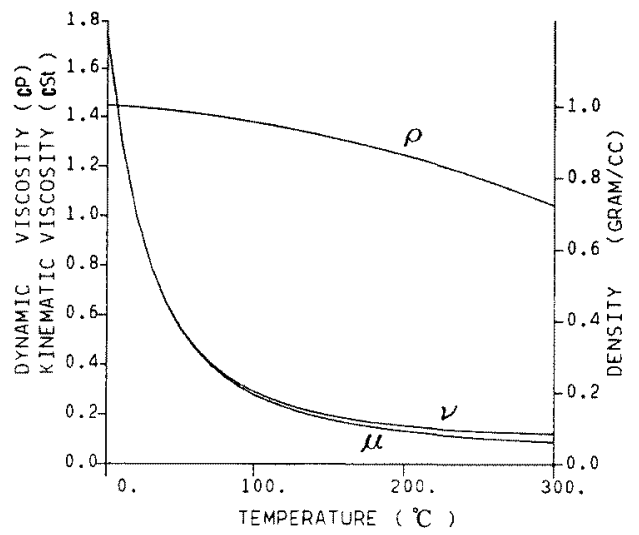

Fig. 5 Change of dynamic viscosity, kinematic viscosity and density of water with temperature.

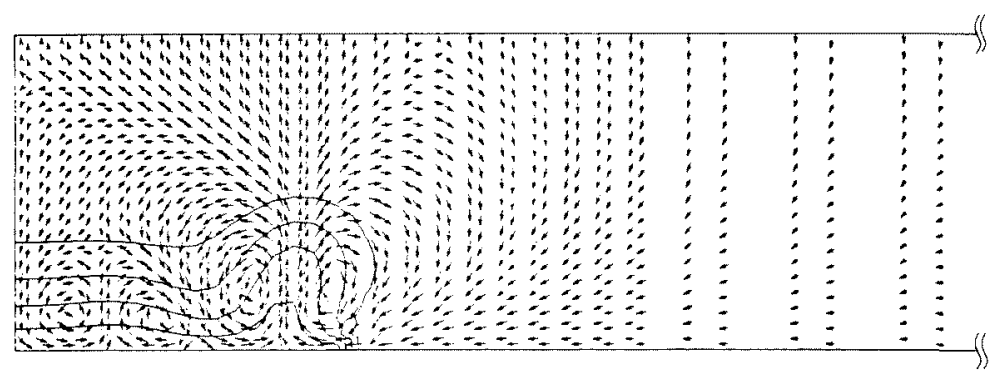

Fig. 6a Calculated flow and temperature with viscosity change shown in Fig. 5 . The input parameters, elapsed time and contour values are the same as those in Fig. 3a.

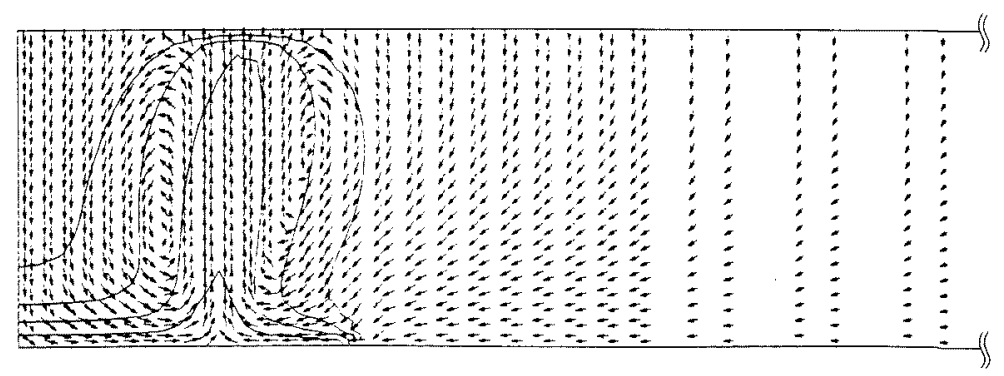

Fig. 6b Calculated flow and temperature with viscosity change shown in Fig. 5 . The input parameters, elapsed time and contour values are the same as those in Fig. $3 b$. 
water is set constant as for water at $125^{\circ} \mathrm{C}$, but it is not appropriate as a realistic property of geothermal water. The kinematic viscosity of water changes depending on temperature as in Fig. 5 and it affects the flow pattern significantly. Fig. $6 \mathrm{a}$ and $6 \mathrm{~b}$ are computed results using the approximation function for viscosity, for the same models of Fig. $3 \mathrm{a}$ and $3 \mathrm{~b}$. It is observed that the change of viscosity affects the pattern and also the rate of the change of the pattern quite significantly.

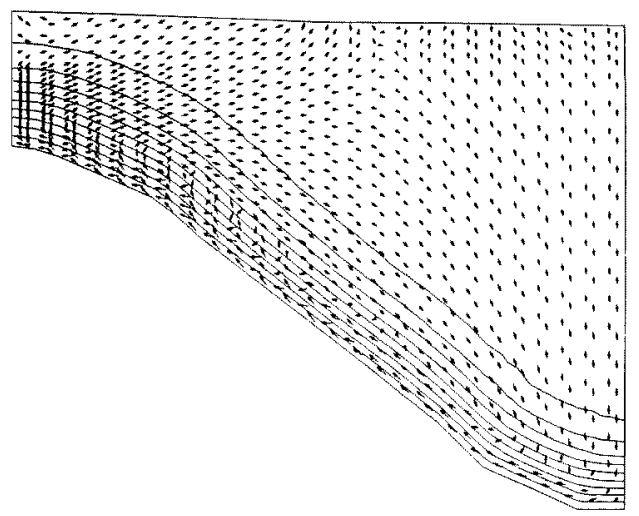

Fig. 7a Calculated flow and temperature on a basement slope. Parameters used are shown in Table 2. Elapsed time is 5,000 years. Tempetature contour interval is $20^{\circ} \mathrm{C}$ (the same for following figures).

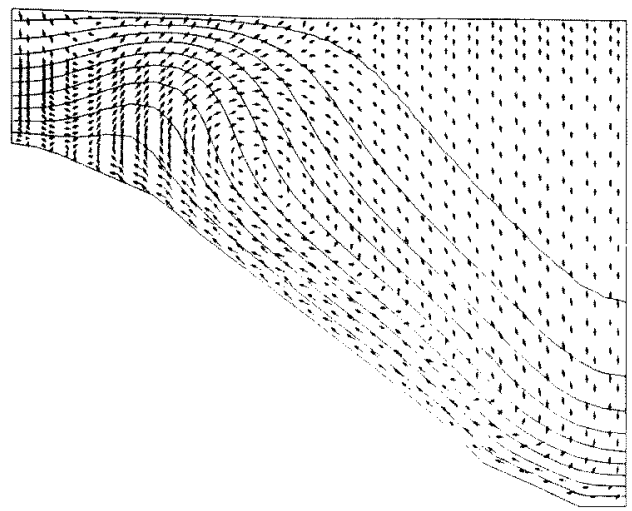

Fig. 7b Calculated flow and temperature at 30,000 years under the same conditions as Fig. 7a.

\section{On a procedure for postulated steady state}

Steady state convection models are of ten used as natural state models, in case the geologic setting may be considered to be constant for a long time range while the hydrothermal system evolves and reaches to a steady state.

A simulation for quite a long time span showed a process of reaching to a steady state. Fig. 7a-7d are calculated flow pattern and temperature for different time starting with an initial condition, by the simulator presented in

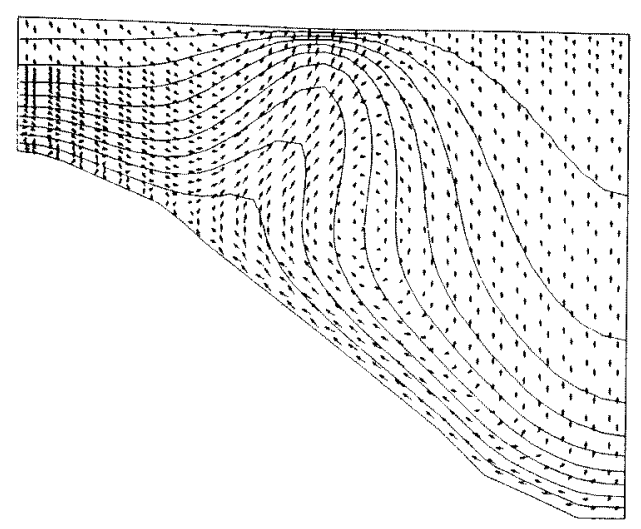

Fig. 7c Calculated flow and temperature at 100,000 years under the same conditions as Fig. 7a.

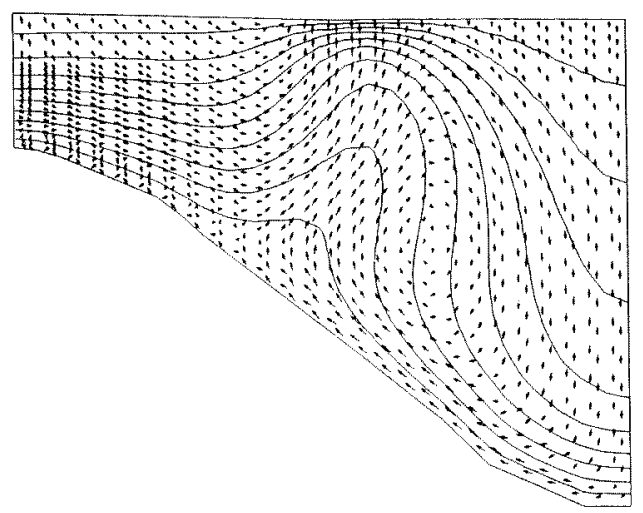

Fig. 7d Calculated flow and temperature at 500,000 years under the same conditions as Fig. 7a. 
Table 2 Input parameters for the models of Figures $7 \mathrm{a}, 7 \mathrm{~b}, 7 \mathrm{c}, 7 \mathrm{~d}, 8$, and 9 .

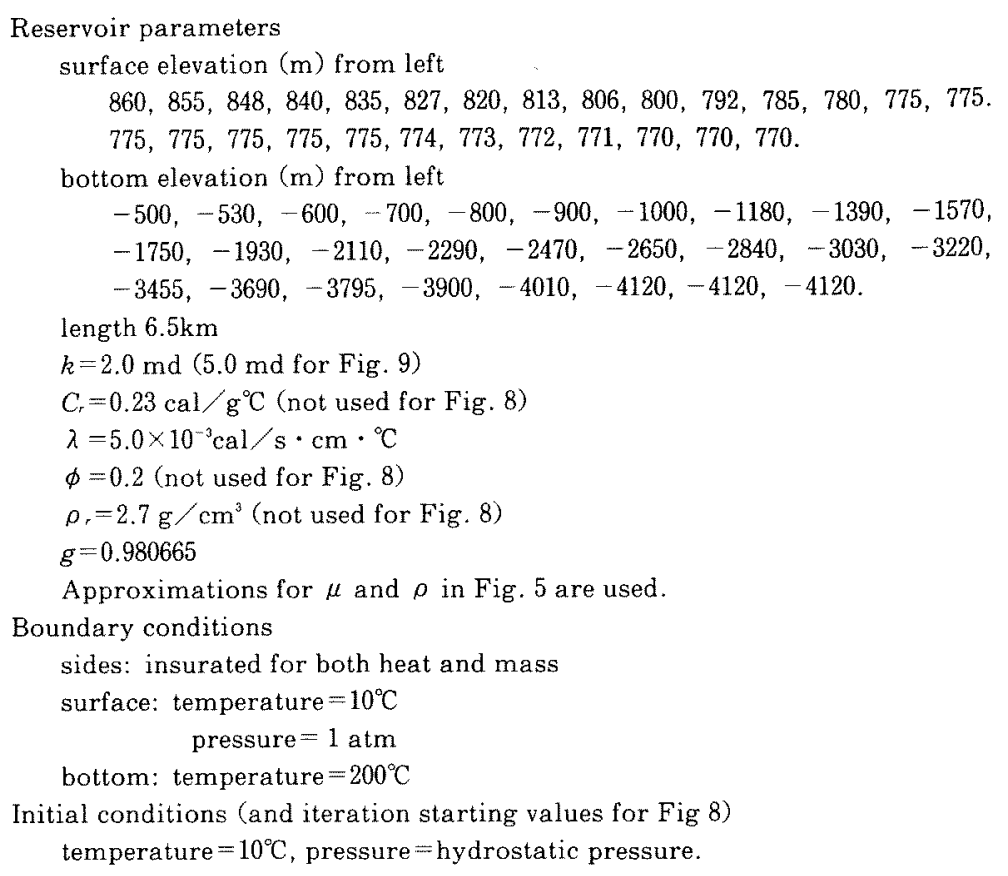

this paper (YANO, et al., 1987a). The parameters used are shown in Table 2. The upflow zone is formed at about 30,000 years after the initial condition. It continues to develop and is pushed downward to the intermediate location on the basement slope. The steady state is reached after about 500,000 years.

If the accumulation terms of the conservation equations were omitted, that is, a steady state is postulated in the simulator itself, we get two discretized equations from (21) and (27) as

$$
\begin{array}{r}
E_{i j} p_{j}+F_{i}-S_{i}=0 \\
G_{i j} h_{j}+S_{i}^{\prime}=0
\end{array}
$$

They are identical to the equations shown by HANAOKA (1980). A steady state of a convection system is calculated by applying boundary conditions to these equations.

Fig. 8 shows a steady state model (YANO et al., 1987b) calculated with equations (39) and $(40)$. The parameters used are the same for the models of Fig. 7, except that the storage

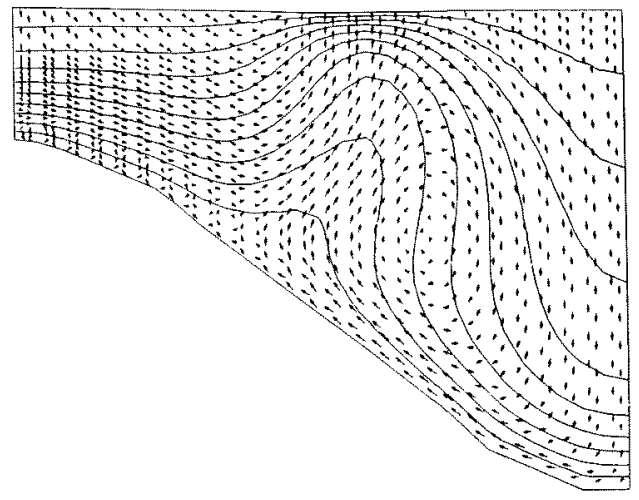

Fig. 8 Steady state flow and temperature on a basement slope calculated by the equations (39) and (40). Parameters used are shown in Table 2.

type parameters such as specific heat, porosity and density of rock are not necessary. In this model, the heat supplied from the slope of the caldera basement and the pressure gradient forced by the upheavement of the 
watertable at the caldera rim are constantly combined to form an upflowing hot zone on the basement slope.

As was shown above, there are two procedures to obtain steady state of a natural geothermal system. One is to use general conservation equations ((21) and (27)) having accumulation terms, and the other is to postulate steady state in the equations to be used ((39) and (40)). The former requires long calculation time starting from the initial condition to reach to the state considered to be constant. The latter seeks that state straightly from appropriate set of initial values and needs rather shorter time. But there are many cases in which the initial values can not be appropriate when the flow pattern is too much complicated or there is no steady state under the boundary condition as in the case of oscillatory convection (Y ANO, 1987). In those cases, the calculation by the latter procedure runs into idle non-convergent iterations. For example, if the permeability for the model of Fig. 8 is changed to higher value as $5 \mathrm{md}$, we can not get to converged values by the postulated steady state procedure. But if we apply the procedure developed here, we can get a convection pattern at an arbitrary time. Fig. 9 is one of the transient flow patterns. In this

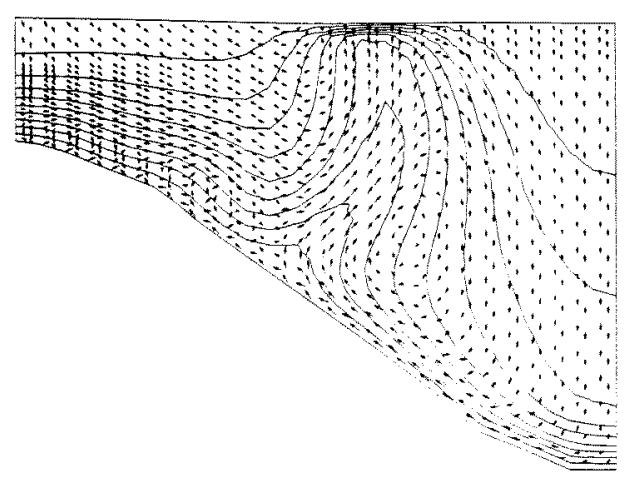

Fig. 9 Calculated transient flow and temperature on a basement slope with higher permeability value than that for Fig. 7 and 8. Parameters used are shown in Table 2. Elapsed time is 500,000 years. case, the condition seems to have no steady state solution. An oscillatory convection is $a b$ served if we trace the change. But as far as the elements can deal the approximation, the procedure can get a result satisfying the physical equations. It seems that tracking natural physical pass to a state is the reasonable way for a numerical calculation.

\section{Conclusion}

A numerical discretization procedure for the simulation of two-dimensional hydrothermal convection was developed using FEM. It was implemented into a FORTRAN program and was verified by comparing its calculated flow pattern with published results. It was found to be applicable both to the simulation of the evolution of a geothermal system and to the calculation of its final steady state. It is based on general conservation equations having accumulation terms, and thus can avoid troubles on convergence which might occur in case the steady state is postulated in the program.

The procedure can easily be implemented into computer programs. The main routines would be those for forming coefficient matrices, assembling and solving the linearlized equations. Miscellaneous subroutines for facilitating data input and output display may help practical use of the simulator.

There are many aspects remained in the research of liquid dominated geothermal systems, such as the effect of the shape and structure of the reservoir, the relation between heat source and the evolution of hydrothermal convection, etc. If there are enough exploration data that can specify parameters for a geothermal reservoir, the simulation study may be useful for further understanding of it. The procedure has a capability for treating them through approximations without excessive simplifications.

\section{Acknowledyments}

The author would like to thank Dr. K. OGAWA and Dr. N. HANAOKA, of Geological Sur- 
vey of Japan, for their valuable comments on the manuscript. Thanks are also due to Prof. $Y$. ISHIl of the University of Tokyo for his encouragement concerning this work.

\section{Nomenclature}

$h \quad:$ fluid enthalpy

$p$ : fluid pressure

$\rho:$ fluid density

$\mu \quad$ : fluid dynamic viscosity

$\nu \quad$ : fluid kinematic viscosity

$C$ : fluid specific heat capacity

$q_{m}$ : mass source

$q_{h}$ : heat source

$T$ : temperature

$\lambda:$ thermal conductivity of reservoir

$k$ : permeability tensor

$\phi$ : porosity

$C_{r}$ : rock specific heat capacity

$\rho$ r : rock density

$h_{r} \quad$ : rock enthalpy

$g$ : gravitational acceleration

$D$ : depth

$t$ : time

$M$ : element area

$N_{i}$ : interpolation function used in the Galerkin approximation

$b_{i j}:$ coefficients of interpolation function

$\beta$ : horizontal angle of the major axis of permeability tensor

$\theta$ : coefficient associated with finite difference approximation of time deriva tive

\section{Unit conversion}

$\lambda: 10^{-3} \mathrm{cal} /\left(\mathrm{cm} \cdot \mathrm{s} \cdot{ }^{\circ} \mathrm{C}\right)=0.4184 \mathrm{~W} /(\mathrm{m} \cdot$ ${ }^{\circ} \mathrm{C}$ )

C: $1 \mathrm{cal} /\left(\mathrm{g} \cdot{ }^{\circ} \mathrm{C}\right)=4.184 \times 10^{3} \mathrm{~J} /\left(\mathrm{kg} \cdot{ }^{\circ} \mathrm{C}\right)$

$k: 1 \mathrm{md}=9.86923 \times 10^{-16} \mathrm{~m}^{2}$

$p: 1$ atm $=1.01325 \times 10^{5} \mathrm{~Pa}$

\section{References}

Bodvarsson, G. S., Pruess, K., Stefansson, V. and Eliasson, E. T., 1984: The Krafla Geothermal Field, Iceland 2. The natural state of the system. Water Resour. Res., 20 (11), pp. 1531-1544.
DOE, 1980: Proceedings of special panel on geothermal model intercomparison study. Sixth Annual Workshop on Geothermal Reseroir Engineering. $120 \mathrm{p}$.

FAUST, C. R. and MERCER, J. W., 1979: Geothermal reservoir simulation 1 , Mathematical models for liquid-and vapor-dominated hydrothermal systems. Water Resour. Res., 15 (1), pp. 23-30.

HANAOKA, N., 1980: A research on integrated analysis - a simulator for hydrothermal systems-. Report on Sunshine research results for fiscal year Showa 53 and 54. Research on the existence of regional and deep geothermal resources, Geological Survey of Japan, pp. 111123 (in Japanese).

INGEBRITSEN, S. E. and SOREY, M. L., 1985: A quantitative analysis of the Lassen hydrothermal system, North Central California. Water Resour. Res., 21 (6), pp. 853-868.

MERCER, J. W. and FAUST, C. R., 1975: Simulation of water-and vapor-dominated hydrothermal reservoirs. Paper presented at 50th Annual Fall Meeting, Soc. Petrol. Eng., AIME.

YANO, Y., 1987: Parameter sensitivity of convection in a caldera. Proceedings. 77th SEGJ Conference, pp. 255-259 (in Japanese with English abstract).

Yano, Y. and HANAOKA, N., 1987: Development of SIGMA : The Geological Survey of Japan, geothermal information database system. Butsuri-Tansa (Geophys, Explor. ), 40 (2), pp. 129-144 (in Japanese with English abstract).

YANO, Y., Kamata, H., and OGAWA, K., 1987a: A model of hydrothermal convection in the Shishimuta caldera, Central Kyushu. Proceedings, 76th SEGJ Conference, pp. 255260 (in Japanese with English abstract).

YANO, Y., KAMATA, H., and OGAWA, K., 1987b: On the conditions for the formation of a hot water convection system above the slope of a caldera basement: Modeling of Shishimuta caldera, Central Kyushu. J. Japan. Assoc. Petrol. Technol., 52 (5), pp. 399-412 (in Japanese with English abstract).

YUSA. Y., 1983: Numerical experiment of ground- 
water motion under geothermal condition vying between potential flow and thermal convective flow. J. Geothermal Res. Soc. Japan, 5 (1), pp. 23-38 (in Japanese with English abst ract).

ZIENKIEWICS, O. C., 1971: The finite element method in engineering science (translated into Japanese by YosHiki M. et al.). Baifukan, Tokyo, 575p.

\section{要約}

有限要素法による垂直 2 次元熱水シミュレー ションのための奏用的手続き

\section{知野雄策}

\section{序 論}

地熱資源評価において熱水流動の数倠シミュレーショ ンは重要な意義を持つ。熱水の物理的举動を扱うには入 力・実行が容搨かつ効率的な2次元断面解析のシミュレー 夕が有効であり，それには有限要菜法が適している。

\section{基喽方程式と離散化}

熱永系に对する質量と工ネルギーの保存を表す一般的 坋微分方程式が FAUST and MERCER (1979) に上っ て示されている(1)式および(2)式)。花岡（1980）は， 定常状態の液相禅相熱水系をシミュレートするたかに， これらの方程式の時間低存項と蒸気に関する項を除き， 3 角形要素を用いたガラーキン有限要素法によって離散 化する手順を示した。ここでは，系の变化状熱す扱うた めに, MERCER and FAUST (1975) による時間微分 の近似法を用い，通常の保存式の形で基礎万程式を離散 化した。液相笚相熱水系に適当である近似 (3)式〜7)式) によってエネルギー保存式好簡略化される(18)式)。両 保存式に内㨉関数をけエレメント領域で積分したもの を解の対象となる方程式とし，部分積分を施す（質量
保存式についてい式および (11) 式。末知数在力括 よびエンタルピとし，エレメント内は各ノードの值で近 似する（(12）式および（13）式)。各時間の值で末知数 およびその微分を近似す机ば（(14）式（15) 式および (22)式)，求めるべき離散化方程式（21）式および（27） 式か得られる。これらの力程式の係数行列は内㨉関数の 微分と積分を用いて（30）式～(36) 式加求められる。 プログラミング上の考慮点

Fig，2は上記のように離散化した力程式を解くた的 のプログラムの流れ図である。大きく分けた手順として， データの人力, 入力データの表示とチェック，内㨂関数 の計算，初期梿のセット，方程式の演算，次の時間ステッッ プへの移行があげられる。プログラムを央用化するたか に比、テー多作成之計算に対して，様々扛夫が必要で ある。

\section{実行とテスト}

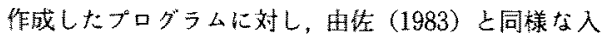
カデータを用い，その結果との比較を行った（Fig，3a， Fig. 3b，Fig. 4)。こ扎よって，ブログラムの正常 動作を確認した。また，動粘度一定を仮定したこの結果 と，粘度に近似関数（Fig.5）を用いた結果の相違も観 祭した（Fig.6a, Fig.6b)。

\section{定常を仮定する手続きとの比較}

ここで求めた最終的な離散化方程式（(21）式かよび (27) 式) から時間依存項を除けば（39）式拈よひ（40) 式が得られこれは花威（1980）と一致する。このよう に，定常状態を方程式自体に仮定すると，本手法のよう に初期値加ら時間を追って求める（Fig.7a-d) 最終的 な定常状黛を一举に求められる（Fig. 8）か，反面，適 当括計算開始值が予测でさない場合や最終的な定常状態 の無い場合等では計算の取束が得られない。通常の保存 則を追ってシミュレートすれば，適当な空間近似，時間 ステップが存在する限り，任意の時点の結果の收束値が 得られる(Fig. 9)。 